\title{
AKUNTABILITAS PENGAWASAN PEMILU YANG BERKUALITAS DAN BERADAB
}

\author{
Muhammad \\ Fisip Universitas Hasanuddin \\ Email : alhamid.muhammad41@gmail.com
}

\begin{abstract}
This article is to analyze the Indonesian General Elections Supervisory Committee's role and performance in its function to have the General Elections completed on the quality and civilized basis. A number of local issues-among others the ones related to the General Elections-potentially contribute to political instability. The underlying factors which undermine the quality of the General Elections are the result of the lack of integrity among the Indonesian Election Commission (KPU) and the Election Supervisory Body (Bawaslu) members. To some extent, this character or personality aspect-an ingrained factor-plays a dominant role in determining their performance, while the capacity aspect which is not an ingrained factor can be acquired through various workshops and trainings.
\end{abstract}

Keywords : the Election Supervisory Body, election, principle, ingrained principles among the Election Supervisory Body members

\begin{abstract}
Abstrak
Artikel ini bertujuan untuk menganalisis pelaksanaan peran pengawas pemilihan umum dalam mewujudkan pemilihan umum yang berkualitas dan beradab. Di Indonesia, sejumlah potensi masalah dalam menciptakan ketidakstabilan politik, termasuk di dalamnya maalah-masalah pemilihan umum. Pada dasarnya, kasuskasus pemilihan umum di Indonesia banyak disebabkan oleh rendahnya integritas penyelenggara pemilihan umum dan kepribadian penyelenggara yang bermasalah, dalam hal ini KPU dan Bawaslu. Dalam sejumlah masalah, aspek karakter penyelenggara pemilihan umum sangat penting diantara sejumlah aspek, karena aspek karakter melekat pada diri seseorang penyelenggara pemilu. Aspek kapasitas dapat dilatih melalui berbagai workshop dan pelatihan.
\end{abstract}

Kata Kunci : Pengawasan Pemilihan Umum, Pemilihan Umum, Prinsip Pengawas Pemilu. 


\section{Pendahuluan}

Sebagaimana dipahami bersama bahwa di kebanyakan negara demokrasi, pemilihan umum dianggap sebagai lambang, sekaligus tolok ukur dari demokrasi itu. Hasil pemilihan umum yang diselenggarakan dalam suasana keterbukaan dengan kebebasan berpendapat dan kebebasan berserikat, dianggap mencerminkan dengan akurat partisipasi serta aspirasi masyarakat. Sekalipun demikian, disadari bahwa pemilihan umum tidak merupakan satu-satunya tolok ukur dan perlu dilengkapi dengan pengukuran beberapa kegiatan lain yang lebih bersifat berkesinambungan, seperti antara lain yang terpenting adalah tingkat partisipasi masyarakat dalam proses pemilihan umum tersebut.

Sebagai bangsa yang terus berupaya mengembangkan kualitas kehidupan demokrasi, tentunya tidak dapat dipungkiri bahwa faktor keterlibatan warga atau masyarakat (partisipasi) dalam proses-proses kehidupan politik dan/atau demokrasi adalah sesuatu yang perlu mendapat perhatian serius, bukan hanya oleh masyarakat itu sendiri, tetapi yang lebih penting sejauhmana pemerintah mampu menstimulus (memotivasi) masyarakat dengan berbagai strategi partisipasi yang lebih baik dan berkualitas guna tercapainya kualitas demokrasi yang memadai.

Pada dasarnya, partisipasi dipahami sebagai kegiatan seseorang atau kelompok orang untuk ikut serta secara aktif dalam kehidupan politik, antara lain dengan jalan memilih pimpinan negara dan / atau daerah, dan secara langsung atau tidak langsung akan mempengaruhi kebijakan pemerintah (public policy). Kegiatan ini mencakup tindakan seperti memberikan suara dalam pemilihan umum, menghadiri rapat umum, mengadakan hubungan (contacting) atau lobbying dengan pejabat pemerintah atau anggota parlemen, menjadi anggota partai atau salah satu gerakan sosial dengan direct actionnya, dan sebagainya. ${ }^{1}$

Sementara itu Samuel P. Huntington (2006,201-203) menjelaskan pengertian partisipasi politik dengan memberi tafsiran yang lebih luas dengan

\footnotetext{
${ }^{1}$ Akan bermanfaat jika mengkaji lebih dalam pemahaman partisipasi politik yang dikemukakan oleh Herbert Mc Closky: Closky berpendapat :"Partisipasi politik adalah kegiatan-kegiatan sukarela dari warga masyarakat melalui mana mereka mengambil bagian dalam proses pemilihan penguasa, dan secara langsung atau tidak langsung, dalam proses pembentukan kebijakan umum (The term political participation will referto those voluntary activities by which members of a society share in the selection of rulers and, directly or indirectly, in the formation of public policy).
} 
memasukkan secara eksplisit tindakan ilegal dan kekerasan. Menurut Huntington, Partisipasi politik adalah kegiatan warga yang bertindak sebagai pribadi-pribadi, yang dimaksud untuk mempengaruhi pembuatan keputusan oleh pemerintah. Partisipasi bisa bersifat individual atau kolektif, terorganisir atau spontan, mantap atau sporadis, secara damai atau dengan kekerasan, legal atau ilegal, efektif atau tidak efektif.

Di negara - negara demokrasi, konsep partisipasi politik bertolak dari pemahaman bahwa kedaulatan ada di tangan rakyat, yang dilaksanakan melalui kegiatan bersama untuk menetapkan tujuan - tujuan serta masa depan masyarakat itu dan untuk menentukan orang - orang yang akan memegang tampuk pimpinan. Jadi, partisipasi politik merupakan pengejawantahan dari penyelenggaraan kekuasaan politik yang absah oleh rakyat.

Anggota masyarakat yang berpartisipasi dalam proses politik, misalnya melalui pemberian suara atau kegiatan lain, terdorong oleh keyakinan bahwa melalui kegiatan bersama itu kepentingan mereka akan tersalur atau sekurangkurangnya diperhatikan, dan bahwa mereka sedikit banyak dapat mempengaruhi tindakan dari mereka yang berwenang untuk membuat keputusan yang mengikat. Dengan kata lain, mereka percaya bahwa kegiatan mereka mempunyai efek politik (political efficacy). Dari penjelasan tersebut, jelaslah bahwa partisipasi politik erat sekali kaitannya dengan kesadaran politik, karena semakin sadar bahwa dirinya diperintah, orang kemudian menuntut diberikan hak bersuara dalam penyelenggaraan pemerintahan.

Di negara - negara demokrasi umumnya dianggap bahwa lebih banyak partisipasi masyarakat, lebih baik. Maksudnya, tingginya tingkat partisipasi menunjukkan bahwa warga mengikuti dan memahami masalah politik dan ingin melibatkan diri dalam kegiatan - kegiatan itu. Hal itu juga menunjukkan bahwa rezim yang bersangkutan memiliki kadar keabsahan (legitimacy) yang tinggi. Maka dari itu, pembatasan yang di masa lalu sering diberlakukan, seperti pembayaran pajak pemilihan (yang di Amerika Serikat pada masa itu merupakan suatu tindakan efektif untuk membatasi partisipasi orang kulit hitam), atau pemilihan hanya oleh kaum pria saja (perempuan Swiss baru mulai tahun 1972 
diberi hak pilih), dewasa ini umumnya telah ditinggalkan (Anthony, 2005, 112114).

Sebaliknya, tingkat partisipasi yang rendah pada umumnya dianggap sebagai tanda yang kurang baik, karena dapat ditafsirkan bahwa banyak warga tidak menaruh perhatian terhadap masalah kenegaraan. Lagi pula, dikhawatirkan bahwa jika berbagai pendapat dalam masyarakat tidak dikemukakan, pimpinan negara akan kurang tanggap terhadap kebutuhan dan aspirasi masyarakat, dan cenderung melayani kepentingan beberapa kelompok saja. Pada umumnya partisipasi yang rendah dianggap menunjukkan legitimasi yang rendah pula.

Selain itu, para pengamat dan teoritisi ilmu politik yang mengamati tentang demokrasi khususnya berkaitan dengan partisipasi cenderung berpendapat bahwa yang dinamakan partisipasi politik hanya terbatas pada kegiatan sukarela saja, yaitu kegiatan yang dilakukan tanpa paksaan atau tekanan dari siapapun. Akan tetapi, sejumlah pengamat / teoritisi lainnya berpendapat berbeda yaitu: kegiatan yang tidak sukarela pun tercakup, karena sulit sekali untuk membedakan antara kegiatan yang benar - benar sukarela dan kegiatan yang dipaksakan secara terselubung, baik oleh penguasa maupun oleh kelompok lain. Huntington dan Nelson misalnya membedakan antara partisipasi yang bersifat otonom (autonomous participation) dan partisipasi yang dimobilisasi atau dikerahkan oleh pihak lain (mobilized participation) ${ }^{2}$. Ada juga yang menamakan gejala terakhir ini sebagai regimented participation.

Dalam hubungan ini mungkin dapat dikatakan bahwa dalam hampir setiap kegiatan partisipasi ada unsur tekanan atau manipulasi, akan tetapi di negaranegara demokrasi Barat tekanan semacam itu jauh lebih sedikit dibandingkan dengan di negara - negara otoriter. Di negara - negara berkembang, seperti Indonesia terdapat kombinasi dari unsur sukarela dan unsur manipulasi dengan berbagai bobot dan takaran.

Di samping mereka yang ikut serta dalam satu atau lebih bentuk partisipasi, ada warga masyarakat yang sama sekali tidak melibatkan diri dalam kegiatan politik. Hal ini adalah kebalikan dari partisipasi dan disebut apati (apathy).

\footnotetext{
${ }^{2}$ Samuel Huntington, No Easy Choice, hlm 7-8
} 
Pertanyaan kemudian yang dapat diajukan adalah: mengapa orang apatis? Ada beberapa kemungkinan jawaban yang dapat diajukan (hipotesis) antara lain: mereka tidak ikut pemilihan karena sikap "acuh tak acuh" dan tidak tertarik pada, atau kurang paham mengenai masalah politik. Ada juga karena tidak yakin bahwa usaha untuk mempengaruhi kebijakan pemerintah akan berhasil, dan ada juga yang sengaja tidak memanfaatkan kesempatan memilih karena kebetuan berada di lingkungan di mana ketidaksertaan merupakan hal yang dianggap biasa.

Jawaban lain yang mungkin muncul bahwa orang itu tidak ikut memilih karena berpendapat bahwa keadaan tidak terlalu buruk dan bahwa siapa pun yang akan dipilih tidak akan mengubah keadaan itu. Dengan demikian ia tidak merasa perlu memanfaatkan hak pilihnya. Jadi "apatis" dalam pandangan ini tidak menunjuk pada rasa kecewa atau frustasi, tetapi malahan sebagai manifestasi rasa puas dan kepercayaan terhadap sistem politik yang ada. Namun yang terpenting untuk dikaji lebih dalam adalah meneliti sebab-sebab mengapa seseorang tidak memberikan suaranya (tidak berpartisipasi)?

Pemilihan umum merupakan salah satu ciri utama sistem politik yang demokratis. Melalui pemilihan umum sirkulasi elit berlangsung secara periodik. Jangka waktu setiap periodik berbeda-beda antara negara yang satu dengan negara lain. Perancis menetapkan pemilihan Presiden setiap 7 tahun, Unite State of America (USA) 4 tahun dan Indonesia 5 tahun. Proses pemilu memberikan peluang untuk terjadinya sirkulasi kepemimpinan atau wakil rakyat berlangsung secara periodik dan demokratis.

Terdapat sejumlah standar umum secara Internasional, yang menjadi tolok ukur demokratis atau tidaknya suatu proses pemilu yang berlangsung. Standar internasional ini muncul menjadi syarat minimal bagi kerangka hukum untuk menjamin pemilu yang demokratis. Indikator dari standar tersebut meliputi 15 aspek yaitu penyusunan kerangka hukum, pemilihan sistem pemilu, penetapan daerah pemilihan, hak untuk memilih dan dipilih, badan penyelenggara pemilu, pendaftaran pemilih dan daftar pemilih, akses kertas suara bagi partai politik dan kandidat, kampanye pemilu yang demokratis, akses ke media massa dan kebebasan berekspresi, pembiayaan dan pengeluaran, pemungutan suara, 
penghitungan dan rekapitulasi suara, peranan wakil partai dan kandidat, pemantauan pemilu, penataan peraturan pemilu, dan penegakan peraturan pemilu. ${ }^{3}$ Kalau terdapat satu atau beberapa aspek yang kurang berjalan dengan baik, maka hal itu akan mempengaruhi aspek-aspek yang lain, sehingga secara keseluruhan akan berdampak pada kualitas pemilu.

Pemilu yang kurang berkualitas akan melahirkan ketidakpuasan bagi banyak kalangan. Ketidakpuasan itu dapat berdampak pada kurangnya kepercayaan masyarakat (public trust) terhadap pemilu. Disamping itu pemilu yang tidak berkualitas akan mendorong lahirnya dinamika politik yang cukup tinggi.

Pelaksanaan pemilu legislatif 2009 yang telah berlangsung, ternyata melahirkan dinamika politik yang cukup tinggi. Dinamika itu disebabkan oleh dua faktor utama. Pertama, partai politik peserta pemilu 38 ditambah partai lokal sebanyak 6 buah. Praktis jumlah peserta pemilu sebanyak 44 buah. Kedua, keputusan Mahkamah Konstitusi (MK) yang menetapkan sIstem suara terbanyak.

Keputusan MK itu berimplikasi luas, karena bukan saja partai politik yang berebut suara rakyat, tetapi juga para caleg dari masing-masing partai. Upaya caleg untuk memperoleh suara terbanyak melahirkan persaingan dan intrik politik cukup tinggi. Persaingan tidak hanya terjadi antara caleg partai politik, tetapi juga terjadi persaingan caleg dalam partai yang sama.

Keinginan para caleg untuk memperoleh suara terbanyak dalam pemilu mendorong para caleg untuk melakukan kampanye personal kepada anggota masyarakat. Praktis para caleg berupaya merebut hati para pemilih. Hal itu berimplikasi pada Daftar Pemilih Tetap (DPT).

Daftar pemilih tetap dinilai banyak kalangan tidak akurat. Hal itu disebabkan oleh 3 faktor. Pertama, tidak ada data kependudukan yang akurat. Ada tiga sebab ketidak akuratan data kependudukan. (1) Penduduk yang pindahpindah. (2) Penduduk yang memiliki KTP ganda. (3) Banyak pendatang baru yang belum terdaftar. Kedua, petugas yang memutakhirkan data tidak bekerja optimal. Ketiga, petugas KPU yang jumlahnya terbatas. Keempat, partisipasi masyarakat

\footnotetext{
${ }^{3}$ Didi Supriyanto,2007, Menjaga Independensi Pemilu, Kata Pengantar Nur Hidayat Sardani, USAID, DRSP, hal., iii.
} 
yang rendah untuk mendaftarkan dirinya secara sukarela sebagai warga negara yang memiliki hak pilih. Keempat aspek tersebut yang menjadi penyebab utama kisruhnya DPT.

Kekisruhan DPT diperparah oleh perhitungan suara di tingkat KPPS. Banyak kalangan menuding tidak sedikit oknum KPPS dan PPK yang melakukan manipulasi suara. Manipulasi suara terjadi dalam 3 bentuk. Pertama, manipulasi dilakukan di tingkat KPPS, baik manipulasi terhadap perolehan suara partai tertentu. Kedua, penggelembungan suara untuk caleg tertentu dalam berita acara C1 di tingkkat KPPS. Ketiga, manipulasi rekapitulasi suara di tingkat kecamatan. Bahkan ditengarai banyak manipulasi terjadi di tingkat KPU, baik kabupaten-kota maupun provinsi.

Praktek manipulasi suara dan money politic merajalela karena dipicu oleh terbukanya peluang yang ada dihadapannya. Adanya peluang melakukan kejahatan politik disebabkan oleh lemahnya pengawasan pemilu, baik pada saat kampanye maupun pada saat perhitungan suara.

Lemahnya pengawasan bukan karena pengawas pemilu mau enaknya saja. Jumlah pengawas pemilu tergolong sedikit, ditambah sarana dan prasarana yang kurang memadai. Akibatnya pelaku kejahatan dalam pemilu dengan leluasa memanfaatkan kelemahan itu. Kondisi tersebut tidak menjamin suara rakyat sampai pada sistem politik. Kalau suara rakyat tidak terjamin sampai pada sistem politik, maka kualitas demokrasi dalam pemilu legislatif dapat dipersoalkan.

Pelaksanaan pemilu yang kurang akuntabel, kurang jujur dan adil, harus mendorong stakeholders pemilu untuk mencari tahu faktor yang menyebabkan munculnya masalah tersebut. Masalah dalam pemilu sangat beragam, mulai dari DPT yang tidak akurat, banyak pemilih yang tidak terdaftar, manipulasi dan penggelembaungan suara, baik di KPPS, PPK, maupun KPU, sehingga melahirkan keresahan dalam masyarakat. Permasalahan penting untuk diajukan yaitu "Bagaimana model dan strategi pengawasan pemilu yang akuntabel, jujur, adil, dan demokratis guna mewujudkan pemilu yang berkualitas dan beradab ?" 


\section{Pembahasan}

Pemilihan umum adalah salah suatu mekanisme pemberian suara oleh rakyat sebagai pemilik mandat atas kedaulatan negara kepada orang atau partai politik yang akan memerintah. Dengan demikian pemilihan umum adalah sarana pelaksanaan kedaulatan rakyat untuk memilih para pemimpinnya yang dianggap mampu untuk melaksanakan tugas pemerintahan guna mencapai tujuan negara.

Di Indonesia, berdasarkan aturan konstitusi, pemilu dilaksanakan setiap 5 tahun sekali untuk memilih para pemimpin pada tiap level pemerintahan baik pemerintah pusat, pemerintah propinsi maupun pemerintah kabupaten / kota. Sebagai sebuah proses yang sangat penting serta menentukan nasib bangsa ini kedepan, maka penyelenggaraan pemilu di Indonesia menganut azas langsung, umum, bebas, rahasia, jujur, dan adil hal ini terutama untuk menjamin bahwa hasil pemilu merupakan pilihan terbaik dari rakyat dan sesuai dengan amanat Pancasila dan Undang-Undang Dasar Negara Republik Indonesia Tahun 1945. Menurut Pasal 18 ayat 3 Undang - undang dasar 1945 Pemerintahan daerah provinsi, daerah kabupaten, dan kota memiliki Dewan Perwakilan Rakyat Daerah yang anggota-anggotanya dipilih melalui pemilihan umum. Pasal 19 ayat 1 anggota Dewan Perwakilan Rakyat dipilih melalui pemilihan umum. Pasal $22 \mathrm{C}$ ayat 1 menyatakan bahwa anggota Dewan Perwakilan Daerah dipilih dari setiap provinsi melalui pemilihan umum. Selain memilih anggota legislative pada setiap level pemerintahan, pemilu juga menjadi sarana untuk memilih kepala eksekutif pemerintahan pada setiap level. Dengan demikian seluruh proses dalam pemilu di Indonesia harus berjalan dengan baik karena terkait dengan hal-hal utama dalam struktur pemerintahan dan pelaksanaan kedaulatan rakyat oleh karena itu asas-asas dalam pemilu harus dapat ditegakkan dengan baik. Guna menjamin hal tersebut maka dibutuhkan penyelenggara dan pengawasan pemilu yang independen dan mampu melaksanakan amanat konstitusi tersebut dengan baik.

\section{Akuntabilitas Pelaksanaan Pemilu}

Sebagai suatu proses yang sangat penting dan diselenggarakan oleh institusi formal maka pelaksanaan pemilu seharusnya dilaksanakan dengan 
mengedepankan prinsip - prinsip akuntabilitas yang didalamnya tercakup aspek transparan dan partisipatif. Menurut Miriam Budiardjo akuntabilitas merupakan pertanggungjawaban pihak yang diberi mandat untuk memerintah kepada mereka yang memberi mandat itu. ${ }^{4}$ Dengan demikian akuntabilitas sebenarnya memiliki makna adanya pertanggungjawaban dengan menciptakan pengawasan melalui distribusi kekuasaan. Hal tersebut penting untuk mengurangi penumpukkan kekuasaan pada suatu lembaga tertentu sekaligus untuk mencipatakan siatuasi saling mengawasi (check and balances). Kondisi tersebut akan memberikan peluang sangat besar bagi penyelenggaraan pemilu yang ideal.

Mengingat bahwa pemilu adalah proses perwujudan dari kedaulatan rakyat terkait pemilihan pejabat pemerintahan maka penyelenggaraan pemilu harus betul-betul dilaksanakan sesuai dengan amanat undang - undang. Guna memastikan hal tersebut maka pelaksanaan pemilu seharusnya dilaksanakan dengan mengedepankan prinsip akuntabilitas.

Prinsip tersebut menuntut dua hal yakni kemampuan menjawab (answerability) dan konsekuensi (consequences). Bagian pertama berhubungan dengan tuntutan bagi para aparat pelaksana untuk memberikan jawaban secara periodik atas berbagai pertanyaan yang terkait dengan penggunaan wewenang mereka dalam menjalankan tugasnya dan bagaimana mereka menggunakan wewenang tersebut dikaitkan dengan penggunaan sumber daya serta hasil yang dicapainya. Dengan demikian seluruh penyelenggara pemilu harus dapat mempertanggung jawabkan pelaksanaan wewenanangnya.

Adapun Guy Peter menyebutkan 3 tipe akuntabilitas yaitu : (1) akuntabilitas keuangan, (2) akuntabilitas administratif, dan (3) akuntabilitas kebijakan publik. ${ }^{5}$ Berdasarkan ketiga hal tersebut maka dapat dikatakan bahwa prinsip akuntabilitas termasuk dalam pelaksaaan pemilu sangat terkait dengan aspek-aspek tersebut. Hal tersebut sangat erat kaitannya dengan upaya akuntabilitas kepada publik.

Pada dasarnya akuntabilitas publik adalah prinsip yang menjamin bahwa setiap kegiatan penyelenggaraan pemerintahan dapat dipertanggung jawabkan

\footnotetext{
${ }^{4}$ Budiardjo Miriam, (2000), Menggapai Kedaulatan untuk Rakyat, Bandung : Mizan.

${ }^{5}$ Peters, B.Guy, (2000) The Politics of Bureaucracy, London : Routledge.
} 
secara terbuka oleh pelaku kepada pihak-pihak yang terkena dampak penerapan kebijakan. Sedangkan dalam bidang politik, yang juga berhubungan dengan masyarakat secara umum, akuntabilitas didefinisikan sebagai mekanisme penggantian pejabat atau penguasa, tidak ada usaha untuk membangun monoloyalitas secara sistematis, serta ada definisi dan penanganan yang jelas terhadap pelanggaran kekuasaan dibawah rule of law. Sedangkan public accountability didefinisikan sebagai adanya pembatasan tugas yang jelas dan efisien. ${ }^{6}$

Berdasarkan penjelasan sebelumnya maka secara garis besar dapat disimpulkan bahwa akuntabilitas terkait dengan kewajiban dari institusi serta para aparat yang bekerja di dalamnya untuk membuat kebijakan maupun melakukan aksi yang sesuai dengan nilai yang berlaku maupun kebutuhan masyarakat. 'Akuntabilitas publik menuntut adanya pembatasan tugas yang jelas dan efisien karena terkait dengan wewenanag dan penggunaan anggaran.

Selanjutnya, hal penting yang terkait dalam akuntabilitas adalah aspek transparansi. Transparansi merupakan prinsip yang menjamin akses atau kebebasan bagi setiap orang guna memperoleh informasi tentang penyelenggaraan suatu kegiatan yang dialkukan oleh suatu institusi negara atau institusi formal lainnya. Informasi yang ada terkait dengan kebijakan, proses pembuatan dan pelaksanaannya, serta hasil-hasil yang dicapai. Dengan demikian aspek transparansi dalam prinsip akuntabilitas akan sangat terkait dengan adanya pengawasan atas seluruh proses yang terjadi. Dengan kata lain transparansi akan memeberikan keterbukaan informasi kepada masyarakat.

Melalui keterbukaan informasi diharapkan akan membuka ruang dinamika politik yang lebih sehat, toleran serta kebijakan didasarkan pada preferensi publik. Prinsip transparansi terkait dengan 2 aspek yakni adanya komunikasi publik dari institusi penyelenggara serta terjaminnya hak masyarakat terhadap akses informasi. Kedua hal tersebut membuthkan kesungguhan dari institusi peyelenggara untuk dapat melaksanaakn kerjanya dengan baik. Secara singkat

\footnotetext{
${ }^{6}$ Lihat dalam, Loina Lalolo Krina, Indikator dan alat ukur prinsip akuntabilitas, transparansi dan partisipasi. Bapenas 2003. Jakarta.
} 
dapat dikatakan bahwa transparansi bermakna tersedianya informasi yang cukup, akurat dan tepat waktu tentang kebijakan publik, dan proses pembentukannya. Dengan ketersediaan informasi seperti ini masyarakat dapat ikut sekaligus mengawasi sehingga kebijakan publik yang muncul bisa memberikan hasil yang optimal bagi masyarakat serta mencegah terjadinya kecurangan dan manipulasi yang hanya akan menguntungkan salah satu kelompok masyarakat saja secara tidak proporsional. Menyimak hal tersebut maka hal penting lain yang juga terdapat dalam prinsip akuntabilitas adalah pertisipasi masyarakat.

Partisipasi adalah prinsip bahwa setiap orang memiliki hak untuk terlibat dalam pengambilan keputusan di setiap kegiatan penyelenggaraan pemerintahan. Keterlibatan dalam pengambilan keputusan dapat dilakukan secara langsung atau secara tidak langsung. Perlu disusun sistem manajemen yang dapat mendorong terwujudnya transparansi dan partisipasi publik, akuntabilitas, taat asas, serta prinsip-prinsip pelaksanaan pemilu.

Guna menjamin hal tersebut dapat terlaksana dengan baik dalam pelaksanaan pemilu maka perlu diperhatikan keberadaan unsur-unsur pendukung akuntabilitas yang meliputi: ${ }^{7}$

1. Penetapan Tujuan dan Sasaran yang jelas, baik untuk jangka pendek maupun jangka menengah. Rencana rehabilitasi dan rekonstruksi harus mengandung visi dan misi yang jelas, sebagai acuan untuk menyusun tujuan dan sasaran rehabilitasi dan rekonstruksi.

2. Struktur Kelembagaan yang solid untuk mendorong terwujudnya sistem manajemen yang efisien dan efektif guna mencapai tujuan dan sasaran yang telah ditetapkan.

3. Penetapan Kebijakan yang jelas dan terarah, konsisten dengan tujuan organisasi, tertulis, dan transparan.

4. Perencanaan yang realistis, terinci dan sesuai dengan kebutuhan, transparan dan partisipatif, akomodatif terhadap sosial budaya masyarakat setempat, dan merupakan penjabaran tujuan dan sasaran yang telah ditetapkan Badan Pelaksana.

\footnotetext{
${ }^{7}$ Loila lalolo krina Ibid. Bapenas 2003. Jakarta.
} 
5. Penetapan Prosedur Kerja yang tepat dan jelas, mudah dilaksanakan, mudah dimengerti dan transparan, serta mempertimbangkan peraturan perundangan yang terkait.

6. Sumber Daya Manusia yang kompeten, profesional dan bermoral.

7. Pelaksanaan Kegiatan yang efektif dan efisien, tertib administrasi, transparan, baik dalam pengadaan barang dan jasa, pengelolaan keuangan, pengelolaan barang inventaris, pengelolaan barang persediaan, maupun pengelolaan barang bantuan.

8. Sistem Pencatatan yang jelas, akurat dan sederhana.

Dengan menganut bernbagai prinsip akuntabilitas maka pelaksanaan pemilu di Indonesia diharapakan akan sesuai dengan amanat undang-undang dan prinsipprinsip demokrasi yang merupakan perwujudan kedaulatan rakyat. Akuntabilitas diharapkan akan dapat memberikan jaminan pelaksanaan dan hasil pemilu yang ideal bagi masyarakat.

\section{Pemilu dan Demokrasi}

Pada dasarnya, prinsip demokrasi yang utama adalah kedaulatan berada ditangan rakyat. Dengan demikian dalam sistem demokrasi, rakyat menempati posisi yang sangat penting. Hal tersebut terkait dengan prinsip kebebasan (liberty) dan persamaan (equality). ${ }^{8}$ Semua rakyat dalam sistem demokrasi memiliki persamaan terkait dengan haknya sebagai warga negara dan hal tersebut dijamin oleh konstitusi. Hak - hak tersebut juga termasuk hak untuk menentukan para pemimpin negara. Penghormatan untuk hal tersebut diwujudkan dalam suatu proses yang disebut pemilu.

Terkait dengan demokrasi, pemilu merupakan suatu mekanisme penyerahan sebagian kedaulatan masyarakat terhadap mereka yang dipilih untuk menjadi pemimpin negara. Hanya saja seringkali hak-hak tersebut terbentur satu sama lain dengan hak-hak serta kepentingan yang lain. Oleh karena itu demokrasi diperlukan karena sistem ini bisa menegakkan stabilitas sosial, menciptakan

\footnotetext{
${ }^{8}$ Lihat Robert A. Dahl, Perihal Demokrasi, Menjelajahi teori dan Praktek Demokrasi secara Singkat. Yayasan Obor Indonesia Jakarta. 2001
} 
ketentraman dan membawa rasa aman atas hak-hak yang dimiliki masyarakat. Demokrasi bukan saja membuat masyarakat mampu mempertahankan dirinya terhadap ancaman yang datang dari luar, tapi juga membina hubungan yang damai antar sesama warga.

Masyarakat yang menempatkan kebebasan sipil (civil liberty) sebagai nilai bersama yang paling mendasar melihat demokrasi dengan cara yang berbeda. Masyarakat ini memerlukan demokrasi untuk melindungi dan menjamin kebebasan dan hak-hak warganya. Tirani dan semua bentuk kekuasaan politik yang bersifat absolut selalu dipandang sebagai ancaman. Demokrasi karenanya kerap diidentikkan dengan upaya mengendalikan dan membatasi kekuasaan negara. ${ }^{9}$

Dalam hal ini prinsip kewarganegaraan (citizenship) menjadi sangat penting. Menurut prinsip ini segala bentuk kekuasaan politik baru dianggap tidak sewenang-wenang dan absah jika mendapat persetujuan masyarakat. Keabsahan atau legitimasi tersebut bisa dicapai, misalnya, melalui pemilihan umum yang dilakukan secara berkala untuk menentukan tokoh dan pemimpin yang menduduki jabatan - jabatan publik dengan wewenang yang besar. Kewarganegaraan juga mengharuskan adanya partisipasi. Maksudnya proses pembuatan kebijakankebijakan bersama yang bersifat otoritatif harus dibuka bagi keterlibatan semua warga dan mempertimbangkan preferensi-preferensi yang berkembang di tengah masyarakat. ${ }^{10}$

Dalam literatur ilmu politik (modern) disebutkan ada beberapa ciri pokok dari sebuah sistem politik yang demokratis, diantaranya: pertama, adanya partisipasi politik yang luas dan otonom; demokrasi pertama - tama mensyaratkan dan membutuhkan adanya keleluasaan partisipasi bagi siapa pun - baik individu maupun kelompok - secara otonom. Tanpa perluasan partisipasi politik yang otonom, demokrasi akan berhenti sebagai jargon politik semata. Oleh karena itu, elemen pertama dalam sebuah sistem politik yang demokratis ialah adanya partisipasi politik yang luas dan otonom. Kedua, berwujudnya kompetisi politik

\footnotetext{
${ }^{9}$ Lihat dalam Muhammad AS Hikam Forum, Perkembangan Pemikiran dan Praktek Demokrasi. 2008

${ }^{10}$ Ibid , Muhammad AS Hikam Forum, 2008.
} 
yang sehat dan adil. Dalam konteks demokrasi liberal, seluruh kekuatan-politik (partai politik) atau kekuatan-sosial-kemasyarakatan (kelompok kepentingan dan kelompok penekan) diakui hak hidupnya dan diberi kebebasan untuk saling berkompetisi secara adil sebagai corong masyarakat, baik dalam pemilihan umum atau dalam kompetisi sosial-politik lainnya. Ketiga, adanya suksesi atau sirkulasi kekuasaan yang berkala, terkelola, serta terjaga dengan bersih dan transparan khususnya melalui proses pemilihan umum. Keempat, adanya monitoring, kontrol, serta pengawasan terhadap kekuasaan (eksekutif, legislatif, yudikatif, birokrasi, dan militer) secara efektif, juga berwujudnya mekanisme checks and balances di antara lembaga-lembaga negara. Serta, kelima, adanya tatakrama, nilai, norma yang disepakati (bersama) dalam bermasyarakat, bernegara, dan berbangsa. ${ }^{11}$

\section{Penutup}

\section{Kesimpulan}

Kehadiran Badan Pengawas Pemilu sebagai instrument penting untuk menjamin legitimasi hasil pemilihan umum tentu harus terus diupayakan dengan mengembangkan strategi berikut:

\section{Pengawasan Preventif}

Sejumlah penanganan pelanggaran pemilu selama ini ditekankan pada tahap ketika suatu pelanggaran telah terjadi yang berimplikasi pada rumitnya penyelesaian pelanggaran tersebut. Ke depan, pengawasan pemilu yang perlu dikembangkan adalah pengawasan pencegahan (preventif), maksudnya, Bawaslu seharusnya lebih berkonsentrasi pada upaya-upaya pencegahan terhadap setiap potensi pelanggaran yang mungkin terjadi, sehingga dapat diantisipasi dan bahkan diminimalkan akses dan resiko yang mungkin terjadi.

\section{Pengawasan Partisipatif}

Bawaslu tentunya memiliki keterbatasan, baik sumber daya maupun sarana untuk dapat melaksanakan fungsi pengawasan secara optimal, oleh karena itu perlu mengajak dan melibatkan unsur masyarakat secara simultan dan sinergi untuk mengawasi pemilu. Masyarakat perlu diguah kesadarannya bahwa

\footnotetext{
${ }^{11}$ Ibid Muhammad AS Hikam Forum, 2008
} 
tanggungjawab pengawasan pemilu tidak hanya berada di pundak bawaslu tapi menjadi tanggungjawab bersama demi terwujudnya pemilu yang berkualitas dan legitimated.

3. Pengembangan dan Perluasan jaringan / sinergitas dengan stakeholders Pemilu.

Beberapa mitra kerja yang dapat mendukung terwujudnya visi dan misi Bawaslu antara lain: Pertama, Pemerintah. sebagai pihak yang memiliki perangkat birokrasi, sumber daya, sarana, prasarana, wewenang pengelolaan anggaran dan keuangan negara, dukungan operasional lainnya, maka bawaslu tentu memerlukan dukungan tersebut demi terwujudnya misi dan terlaksananya tupoksi / wewenang / kewajiban Bawaslu secara optimal, proporsional dan profesional berdasarkan peraturan PerUndang - Undangan yang berlaku. Kedua, DPR. DPR dan Bawaslu sejatinya memiliki misi yang sama dan sejalan untuk mengawasi pelaksanaan proses-proses politik di negeri ini khususnya Pemilihan Umum. Bawaslu tentu membutuhkan dukungan politiik dari wakil rakyat terutama untuk mengawal prinsip dan karakter independensi, keberdayaan dan ketegasan Bawaslu melalui perangkat UU yang menguatkan prinsip dan karakter tersebut. Ketiga, Perguruan Tinggi, Bawaslu selalu membutuhkan kajian-kajian akademis yang kritis dan obyektif tentang kepemiluan terutama fungsi pengawasan agar dapat mempertajam dan menguatkan keandalan / profesionalisme bawaslu. Selain itu, Ketika saya mengembang amanah sebagai Ketua Panwaslu Sul Sel, saya bekerja sama dengan pihak pengelola Kuliah Kerja Nyata (KKN) Universitas Hasanuddin untuk melibatkan peserta KKN dalam pengawasan pemilu. Hasilnya, banyak temuan-temuan mahasiswa peserta KKN yang dapat membantu panwaslu Sul Sel dalam menindaklanjuti laporan - laporan masyarakat. Keempat, Lembaga Swadaya Masyarakat. Bawaslu juga membutuhkan dukungan LSM dan Lembaga-lembaga Peduli Pemilu lainnya untuk secara bersinergi mengawasi pelaksanaan dan penyelenggara pemilu serta stakeholders kepemiluan lainnya. Kelima, Partai Politik. Terwujudnya pelaksanaan pemilu yang jujur, adil, kredibel dan bertanggung jawab tentunya tidak hanya menjadi domain dan tanggung jawab KPU dan Bawaslu, tapi juga peserta pemilu (partai politik) 
terutama ketika mengajak, mendidik dan mengarahkan kader / pengurus serta simpatisannya pada perilaku politik yang dewasa, santun, dan bertanggung jawab. Keenam, Media. Bawaslu membutuhkan dukungan media terutama dalam mempublikasikan dan mengajak masyarakat untuk berperan aktif dalam pengawasan pemilu. Keterbatasan sarana publikasi yang dimiliki Bawaslu tentu menjadi kendala tersendiri bagi terdistribusinya informasi pengawasan pemilu kepada masyarakat. Melalui media pula, bawaslu akan mendapatkan banyak sumber informasi, data dan fakta yang dapat diolah dan dijadikan sebagai kekuatan dalam menjalankan tugas pengawasan pemilu.

Strategi yang tepat untuk menghindari intervensi negatif dari pihak lain antara lain: Pertama, memantapkan tekad dan keyakinan bahwa keteguhan komitmen akan integritas yang kokoh adalah "harga mati" yang harus terus ditegakkan. Menurut saya, persoalan integritas kokoh adalah faktor pertama dan utama menentukan kemampuan seorang anggota Bawaslu untuk menghindari intervensi negatif dari pihak manapun. Ini adalah faktor internal dalam diri seseorang yang hanya bisa dilatih dan dibentuk oleh individu yang bersangkutan. Kedua, menjaga soliditas, solidaritas dan konsistensi internal sesama pengawas pemilu. Setelah masing-masing pengawas pemilu sudah membangun karakter individu yang berintegritas, langkah berikutnya adalah mensinergikan kekuatankekuatan integritas individu tersebut menjadi sebuah task force yang kokoh. Ketiga, mengembangkan kemampuan, keterampilan dan teknik pengawasan yang andal pada semua level pengawasan pemilu. Hal ini penting untuk memberikan bekal bagi aparat pengawasan pemilu untuk jeli dan cermat dalam "menemukenali" setiap oknum dan/atau kelompok yang ingin melakukan intervensi negative terhadap Bawaslu dan jajarannya. Keempat, mendesain regulasi pengawasan pemilu yang lebih komprehensif, detail dan sistematik termasuk mengatur sanksi yang lebih jelas dan tegas, agar dapat meminimalkan celah yang dapat dimanfaatkan oleh pihak-pihak yang ingin mengintervensi secara negatif Bawaslu dan jajarannya. 


\section{Saran}

1. Upaya mewujudkan akuntabilitas pengawasan pemilu yang berkualitas dan beradab, sangat ditentukan oleh hadirnya pengawas pemilu yang jujur dan berintegritas. Oleh karena itu segenap stakeholders pemilu seharusnya bersinergi dalam mewujudkan hal tersebut.

2. Akuntabilitas pengawasan pemilu juga sangat ditentukan oleh komitmen dan konsistensi dalam penegakan hukum (law enforcement) oleh aparat penegak hukum. Sekaitan dengan hal tersebut, aparat penegak hukum harus senantiasa bersinergi dalam mewujudkan hal tersebut.

\section{DAFTAR PUSTAKA}

Almond, Gabriel, dan Sidney Verba. Budaya Politik: Tingkah Laku Politik dan Demokratisasi di Lima Negara. Jakarta: Bina Aksara, 1984.

Apter, David. Politik Modernisasi. Jakarta: Gramedia, 1987.

AS Hikam, Mohammad. Perkembangan Pemikiran dan Praktek Demokrasi. Forum Jakarta, 2008.

Asian Development Bank. Governance : Sound Development Management,1999.

Budiardjo Miriam. Menggapai Kedaulatan untuk Rakyat, Bandung : Mizan, 2000.

Dahl, Robert. On Democracy. New Haven: Yale University Press, 1999.

Diamond, Larr. The Democratic Revolution. London: Freedom House, 1992.

Diamond, Larry, Juan Linz, dan Seymour Lipset (Eds.). Democracy in Developing Countries: Comparing Experiences With Democracy. Boulder: Lynne Rienner, 1990.

Harrison, Lawrence, dan Samuel Huntington. Culture Matters: How Values Shape Human Progress. New York: Basic Books, 2000.

Held, David (Ed). New Form of Democracy. London: SAGE, 1986.

Held, David. Model of Democracy. Cambridge: Polity Press, 1990.

Huntington, Samuel. The Third Wave Democratization in the Late Twentieth, 1991. 
140 ADIL : Jurnal Hukum Vol. 3 No.1

O’Donnell, Guillermo, dan Phillipe C. Schmitter. Transisi Menuju Demokrasi: Rangkaian Kemungkinan dan Ketidakpastian. Jakarta: LP3ES, 1993. O’Donnell, Guillermo, Phillipe C. Schmitter, dan Laurence Whitehead. Transisi Menuju Demokrasi: Tinjauan Berbagai Perspektif. Jakarta: LP3ES, 1993. 